\title{
Effects of Seasonal Variation on the Physicochemical Characteristics of Iyifeyi Stream in Ugwobi Abbi, Enugu State Nigeria
}

\author{
Onuorah Samuel ${ }^{1, *}$, Ndumdi Dominic ${ }^{1}$, Okoye Patrick ${ }^{2}$ \\ ${ }^{1}$ Department of Applied Microbiology and Brewing, Nnamdi Azikiwe University, Awka, Anambra State, Nigeria \\ ${ }^{2}$ Department of Pure and Industrial Chemistry, Nnamdi Azikiwe University, Awka, Anambra State, Nigeria
}

Received March 11, 2020; Revised May 4, 2020; Accepted May 20, 2020

Copyright $(2020$ by authors, all rights reserved. Authors agree that this article remains permanently open access under the terms of the Creative Commons Attribution License 4.0 International License

\begin{abstract}
Water is the most abundant of all known chemical substances, which occur naturally on the surface of the earth. Iyifeyi stream is the major source of drinking water for the inhabitants of Ugwobi Abbi in Uzo-Uwani Local Government Area of Enugu State, Nigeria. The stream shows significant reduction in volume during the dry season but increases in volume during the rainy season, therefore, studies were conducted on it to determine the effects of seasonal variation on the physicochemical characteristics, with a view to determining its suitability for drinking. Samples were collected in triplicates upstream, midstream and downstream during the dry and wet seasons and analyzed physicochemically using the standard methods for the examination of water and wastewater. The results showed that the colour, turbidity, temperature, electrical conductivity, total dissolved solids, total suspended solids, total acidity, total hardness, total chloride, sulphate, nitrate, nitrite, biological oxygen demand, iron and aluminum were within the WHO standard for drinking water quality during both seasons while the $\mathrm{pH}$, chemical oxygen demand and lead levels were not. This indicated that the water from the stream is unfit for drinking without adequate treatment. Liming, filtration, boiling and ozonation are recommended.
\end{abstract}

Keywords Water, Iyifeyi Stream, Seasonal Variation, Physicochemical Parameters, Dry Season, Wet Season, Ugwobi Abbi

\section{Introduction}

Water is fundamentally important to all plants, animals and man [1] and its properties determine many natural phenomena. Man uses water for various purposes which include drinking, transportation, industrial and domestic use, irrigation in agriculture, recreation, fisheries and waste disposal among others [2,3]. Water that is good for drinking is important to human physiology and man's continued existence depends so much on its availability $[2,3]$.

Potable water is a fresh water body that is unpolluted, suitable for drinking, odourless and tasteless [4]. It boils at $100^{\circ} \mathrm{C}$, freezes at $0^{\circ} \mathrm{C}$, is neutral to litmus and has an atmospheric pressure of $760 \mathrm{mmHg}$. It could be tapped from underground aquifers via wells or boreholes, be harvested as rain (precipitation) from the atmosphere as is the practice in most communities and fetched from surface water sources like rivers, streams, lakes, ponds, oases, seas or even oceans. Surface water has the basic advantage of being comparatively cheaper and very easy to access [4].

Pollution of surface water occurs when much of an undesirable or harmful substances flow into it, exceeding its natural ability to remove the undesirable material, dilute it to a harmless concentration or convert it to harmless form. This can be from point or non- point source [4]. The presence of certain chemicals such as iron, copper, zinc, cobalt, manganese, selenium, chromium, aluminum, ammonia, nitrite, calcium, phosphate, sulphate and nitrate in water can also be detrimental to human health [5]. It is estimated that $80 \%$ of all illnesses in developing countries is related to water and sanitation and that $15 \%$ of all child deaths under the age of 5 years in developing countries results from diarrheal diseases $[6,7]$.

Iyifeyi stream is located at Owereze village in Ugwuobi community. No industry or refuse dump is located near the stream. However, run- offs from agricultural lands empty their contents into the stream during the wet season. The stream serves as the major source of water for drinking, bathing, swimming and other purposes for the people of the 
community during the dry and wet seasons, hence this study will create awareness on the physicochemical quality of the Iyifeyi Stream within the Ugwobi Abbi Community during both seasons and recommends possible means of treatment of the water before use.

\section{Materials and Methods}

\subsection{Study Area}

The research was on Iyifeyi Stream in Ugwobi Abbi, Uzo-Uwani Local Government Area of Enugu State. The community is located on high plain with a small flat top and farming is the major occupation of the people of the community. Its geographical coordinates are $6^{\circ} 50^{\prime} 0$ " North, $7^{\circ} 14^{\prime} 0$ " East and its original name was Abbi. Uzo- Uwani Local Government Area is characterized by tropical climate with distinct wet and dry seasons and borders Kogi and Anambra States.

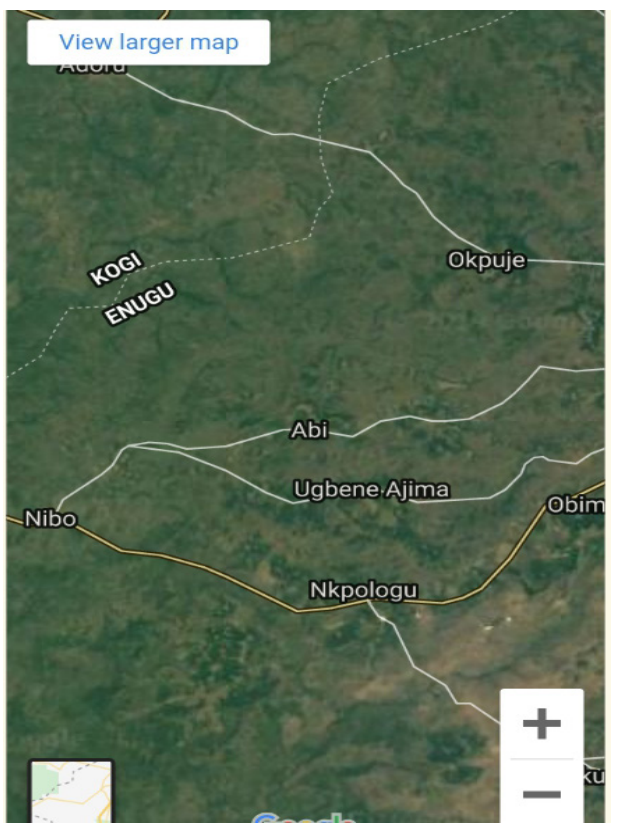

Figure 1. Map of Abbi in Uzo-Uwani L.G.A. of Enugu State, Nigeria

\subsection{Study Design}

Two sampling seasons were employed (wet and dry seasons) and the samples were randomly collected from the stream during both seasons. The dry season samples were collected from November 2015 to January 2016 while the wet season samples were collected between May and July, 2016.

\subsection{Samples Collection}

Water samples for physicochemical analysis were collected using freshly blown plastic water containers. The sampling points were upstream, midstream and downstream. Three samples were collected from each of the three sampling points. Prior to sample collection, the containers were thoroughly rinsed with the water to be sampled. The samples were transported to the laboratory of Acckk Industries Limited Awka, Anambra State, Nigeria where they were analysed.

\subsection{Determination of Physicochemical Parameters}

The physicochemical parameters were determined according to the procedures described by APHA [8]. Colour, turbidity, temperature, $\mathrm{pH}$, electrical conductivity, total dissolved solids, total suspended solids, total acidity, total hardness, total chloride, sulphate, nitrate, nitrite, biochemical oxygen demand, chemical oxygen demand, iron, lead, zinc, copper and aluminium were determined.

\subsubsection{Determination of Colour}

This was determined using the Multi Parameter Bench Photometer manufactured by HANNA (India). One cuvette was filled up to the $10 \mathrm{ml}$ mark with deionized water and the cap replaced. This was the blank. Another cuvette was filled up to the $10 \mathrm{ml}$ mark with unfiltered sample and the cap replaced. This was the apparent color. $50 \mathrm{ml}$ of water sample were filtered through a $0.45 \mu \mathrm{m}$ filter membrane into a beaker. The third cuvette was filled up to the $10 \mathrm{ml}$ mark with the filtered sample and the cap replaced. This was the true color. The blank was placed into the cuvette holder and the lid closed. The Zero key was pressed and the meter was zeroed. The cuvette was removed and the apparent color cuvette was inserted into the instrument and the lid closed. The Read key botton was pressed and the meter directly displayed the value of the apparent color. The cuvette was removed and the true color cuvette was inserted into the instrument and the lid closed. The Read key was pressed and the meter displayed the result in True Colour Unit (TCU).

\subsubsection{Determination of Turbidity}

This was determined using a Turbidimeter manufactured by $\mathrm{HACH}$ (India). The operating range was selected at AUTO mode. A clean sample cell was filled to the mark with the test sample and placed in the cell holder. The sample was covered with the light shields. The instrument displaced the value in Nephelometric Turbidity Unit (NTU).

\subsubsection{Measurement of Temperature}

This was measured in situ at the site of sample collection using a mercury in glass thermometer by placing the probe in the water. The result was taken after the reading stabilized.

\subsubsection{Determination of $\mathrm{pH}$}

The $\mathrm{pH}$ of the water samples was determined using a $\mathrm{pH}$ meter manufactured by HANNA (India). The $\mathrm{pH}$ meter 
was first standardized with $\mathrm{pH}$ buffers 4.0 and 7.0 before performing the test. $100 \mathrm{ml}$ of each of the samples were poured into a sterile beaker and the anode of the $\mathrm{pH}$ meter was dipped into it. The $\mathrm{pH}$ value was obtained when the meter reading stabilized.

\subsubsection{Determination of Electrical Conductivity}

This was determined using a conductivity meter manufactured by HANNA (India). $100 \mathrm{ml}$ of each water sample were poured into a clean beaker. The electrode was placed in the sample, stirred and the result was taken after the meter reading became stable.

\subsubsection{Determination of Total Dissolved Solids}

An evaporating dish was dried and weighed. The sample was stirred and one litre was filtered through a filter paper and washed three times. The filtrate was transferred into an evaporating dish and dried. The dish was cooled and thereafter weighed.

$$
\begin{aligned}
& \text { Total dissolved solids }(\mathrm{mg})=\frac{(A-B) \times 100}{\text { volume of sample }} \\
& (\mathrm{mg} / \mathrm{l})=\frac{(A-B) \times 100}{\text { volume of sample }}
\end{aligned}
$$

Where $\mathrm{A}=$ weight of dried residue + dish (mg).

$\mathrm{B}=$ weight of dish (mg).

\subsubsection{Determination of Total Suspended Solids}

A filter paper was weighed. One liter of the sample was filtered through the weighed filter paper. The filter paper was allowed to dry completely and reweighed.

$$
\text { Total suspended solids }(\mathrm{mg} / \mathrm{l})=\frac{(A-B) \times 100}{\text { volume of sample }}
$$

Where $\mathrm{A}=$ weight of dried residue + filter paper $(\mathrm{mg})$.

$\mathrm{B}=$ weight of filter paper $(\mathrm{mg})$.

\subsubsection{Determination of Total Acidity}

Fifty mililitres of the sample were pipetted into a conical flask and 2 drops of methyl orange indicator solution were added. The burette was filled with $0.02 \mathrm{~N} \mathrm{NaOH}$ solution and titrated till the colour of the solution changed to faint orange colour, indicating the end point. The volume of titrant consumed was recorded as $\mathrm{V}_{1}$ in $\mathrm{ml}$. The methyl orange acidity (total acidity) was calculated as follows:

$$
\text { Methyl orange acidity }(\mathrm{mg} / \mathrm{l})=\frac{\mathrm{V}_{1} \times 1000}{\text { volume of sample }}
$$

Where $\mathrm{V}_{1}$ is volume of titrant consumed.

\subsubsection{Determination of Total Hardness}

This was determined by treating one hundred millilitres of water sample with $4 \mathrm{ml}$ of ammonium buffer solution and three drops of Eriochrome Black $\mathrm{T}$ indicator. The solution was titrated with $0.02 \mathrm{~N}$ EDTA (Ethylene diaminotetra acetic acid) until the color changed from red to blue. The result was calculated by multiplying the volume of EDTA used by 100 .

\subsubsection{Determination of Chloride}

Five drops of phenolphthalein indicator solution were added to $50 \mathrm{ml}$ of the water sample and neutralized with $0.25 \mathrm{~N}$ sodium hydroxide till the mixture became colorless. $1 \mathrm{ml}$ of potassium dichromate indicator solution was added before titration with standard silver nitrate solution to the pinkish-yellow endpoint. A reagent blank titration was carried out in parallel to the sample titration. Chloride concentration was calculated as follows; Chloride $(\mathrm{mg} / \mathrm{l})=[(\mathrm{A}-\mathrm{B})(\mathrm{N})(35.45) / \mathrm{V}] \times 100$, where $\mathrm{A}=$ silver nitrate solution in $\mathrm{ml}$ for sample titration; $\mathrm{B}=$ silver nitrate solution used for blank titration (in $\mathrm{ml}$ ) : $\mathrm{N}=$ Normality of silver nitrate solution, $\mathrm{V}=$ sample volume $(\mathrm{ml})$, $35.45=$ standard atomic weight of chlorine.

\subsubsection{Determination of Sulphate}

This was determined using the Multi Parameter Bench Photometer manufactured by HANNA (India). The sulphate method was selected using the up and down keys of the photometer. A cuvette was filled with $10 \mathrm{ml}$ of unreacted sample and the cap was replaced. The cuvette was placed into the holder of the photometer and the lid was closed. The Zero key was pressed to initialize the instrument and the cuvette was removed. The content of one packet of HI 93751-0 indicator reagent was added to the cuvette, the cap was replaced and it was mixed for one minute by inverting the cuvette gently. The cuvette was thereafter reinserted into the instrument. The Timer key was pressed and the instrument displayed concentration of sulphate $\left(\mathrm{SO}_{4}{ }^{2-}\right)$ in $\mathrm{mg} / \mathrm{l}$.

\subsubsection{Determination of Nitrate}

This was determined by using the Multi Parameter Bench Photometer manufactured by HANNA (India). The nitrate method was selected using the up and down keys of the photometer. A cuvette was filled with $6 \mathrm{ml}$ of sample using a pipette and the cap was replaced. The cuvette was placed into the holder of the photometer and the lid was closed. The instrument was initialized by pressing the Zero Key. The cuvette was removed and one packet of HI 93728-0 reagent was added. The cap was replaced and shaken vigorously for exactly 10 seconds and allowing it to mix by inverting the cuvette gently for 50 seconds. The cuvette was reinserted into the instrument and the Timer Key was pressed and the instrument displayed the results in $\mathrm{mg} / \mathrm{l}$ of nitrate $\left(\mathrm{NO}_{3}{ }^{-}\right)$.

\subsubsection{Determination of Nitrite}

This was determined with the Multi Parameter Bench Photometer manufactured by HANNA (India). The nitrite method was selected using the up and down keys of the photometer. The cuvette was filled with $10 \mathrm{ml}$ of unreacted 
sample and the cap was replaced. The cuvette was placed into the holder of the photometer and the lid was closed. The Zero key was pressed to initialize the instrument and the cuvette was removed. One packet of HI 93707-0 reagent was added to the cuvette and the cap was replaced and the cuvette was thereafter shaken gently for 15 seconds before reinsertion into the instrument. The Timer key was pressed and the instrument displayed concentration of nitrite in $\mathrm{mg} / \mathrm{l}$.

\subsubsection{Determination of Biological Oxygen Demand (BOD)}

Four $300 \mathrm{ml}$ BOD bottles were selected and $10 \mathrm{ml}$ of samples were added to two of the bottles and the remaining volume was filled with the dilution water. The $\mathrm{pH}$ of the samples was adjusted to 7 by adding $1 \mathrm{~N}$ sodium hydroxide. The remaining two BOD bottles were filled with dilution water and served as the blank. The bottles were closed immediately avoiding air bubbles. One sample and one blank bottle were analyzed immediately for dissolved oxygen (DO). The remaining one blank and one sample bottle were incubated at $20^{\circ} \mathrm{C}$ for 5 days in an incubator and analyzed for dissolved oxygen (DO).

$$
B O D_{5}(m g / L)=\frac{D_{1}-D_{2}}{P}
$$

$\mathrm{D} 1=$ initial DO of sample $(\mathrm{mg} / \mathrm{l})$.

$\mathrm{D} 2=$ Final DO of sample $(\mathrm{mg} / \mathrm{l})$

$\mathrm{P}=$ decimal volumetric fraction of sample used.

\subsubsection{Determination of chemical oxygen demand (COD)}

Ten millilitres of water sample were poured in three 100 $\mathrm{ml}$ conical flasks labeled as Test 1 , Test 2 and Test 3 . Simultaneously, distilled water was poured in another three $100 \mathrm{ml}$ conical flasks labeled as Blank 1, Blank 2 and Blank 3. $5 \mathrm{ml}$ of potassium dichromate solution were added to each of the six conical flasks. The flasks were kept in a water bath at $100^{\circ} \mathrm{C}$ for 1 hour and allowed to cool for 10 minutes. $5 \mathrm{ml}$ of potassium iodide and $10 \mathrm{ml}$ of sulphuric acid were thereafter added to each flask and the content of each flask was titrated with $0.1 \mathrm{~N}$ Sodium thiosulphate until the blue color disappeared completely.

$$
\operatorname{COD~}(\mathrm{mg} / \mathrm{l})=\frac{(\mathrm{a}-\mathrm{b}) \times \mathrm{c} \times 1000}{\text { Volume of sample }}
$$

$$
\begin{aligned}
& \mathrm{a}=\text { titrant used for samples } \\
& \mathrm{b}=\text { titrant used for blank } \\
& \mathrm{c}=\text { normality }
\end{aligned}
$$

\subsubsection{Determination of Iron}

This was determined using the Multi Parameter Bench Photometer manufactured by HANNA (India). The required reagents were two packets of HI 93746-0 (low range iron reagent). The Iron method was selected using the up and down keys of the photometer. One graduated measuring cylinder was filled up to the $25 \mathrm{ml}$ mark with deionized water. The content of one packet of HI 93746-0 reagent (low range iron reagent) was added to the cylinder and shaken vigorously for 30 seconds. This was the blank. A cuvette was filled with $10 \mathrm{ml}$ of the blank and the cap was replaced. The cuvette was placed into the holder of photometer and the lid was closed. The meter was initialized by pressing the Zero key and the cuvette was removed. Another graduated measuring cylinder was filled up to the $25 \mathrm{ml}$ mark with the sample. The content of one packet of HI 93746-0 reagent was added to the cylinder and shaken vigorously for 30 seconds. This was the reacted sample. A cuvette was filled with $10 \mathrm{ml}$ of the reacted sample and the cap was replaced. The sample was inserted into the instrument and the Timer key was pressed and the meter displayed the reading in $\mathrm{mg} / \mathrm{l}$ of iron.

\subsubsection{Determination of Lead}

This was determined using the Multi Parameter Bench Photometer manufactured by HANNA (India). The lead method was selected using the up and down keys of the photometer. A cuvette was filled with $10 \mathrm{ml}$ of unreacted sample and the cap was replaced. The cuvette was placed into the holder of the photometer to initialize the meter. The cuvette was removed and the content of one packet of HI $93740 \mathrm{~A}-0$ was added. The cap was replaced and the cuvette was shaken for 15 minutes after which it was reinserted into the instrument and the Timer key was pressed. The meter displayed the reading in $\mathrm{mg} / \mathrm{l}$ of lead.

\subsubsection{Determination of Zinc}

This was determined using the Multi Parameter Bench Photometer manufactured by HANNA (India). The zinc method was selected using the up and down keys of the photometer. One graduated measuring cylinder was filled up to $20 \mathrm{ml}$ mark with the sample. The content of one packet of HI 93731 A-O zinc reagent was added and the cylinder was closed and mixed by inverting it several times. One cuvette was filled with $10 \mathrm{ml}$ of the reacted sample and the cap was replaced. The cuvette was inserted into the instrument to initialize the meter by pressing the Zero key. The cuvette was removed and $0.5 \mathrm{ml}$ of HI 93731B-O cyclohexanone was added to it. The cap was replaced and the sample was mixed for 15 seconds and inserted into the instrument. The Timer key was pressed and the meter displayed the reading in $\mathrm{mg} / \mathrm{l}$ of zinc.

\subsubsection{Determination of Copper}

This was determined using the Multi Parameter Bench Photometer manufactured by HANNA (India). The copper method was selected using the up and down keys of the photometer. A cuvette was filled with $10 \mathrm{ml}$ of unreacted sample and the cap was replaced. The cuvette was placed into the holder of the photometer to initialize the meter. The cuvette was removed and the content of one packet of 
HI 95747-0 bicinchoninate was added. The cap was replaced and the cuvette was shaken for 15 minutes. The cuvette was thereafter reinserted into the instrument and the Timer key was pressed and the meter displayed the result in $\mathrm{mg} / \mathrm{l}$ of copper.

\subsubsection{Determination of Aluminum}

This was determined with the aid of the Multi Parameter Bench Photometer manufactured by HANNA (India). The aluminum method was selected using the up and down keys of the photometer. A cuvette was filled with $10 \mathrm{ml}$ of unreacted sample and the cap was replaced. The cuvette was then placed into the holder of the photometer to initialize the meter and thereafter removed and the content of one packet of HI 93840-03 was added. The cap was replaced and the cuvette was shaken for 15 minutes and reinserted into the instrument. The Timer key was pressed and the meter displayed the reading in $\mathrm{mg} / \mathrm{l}$ of aluminum.

\section{Results}

The physical parameters investigated in the water samples during the dry and wet seasons are presented in Table 1. The results for the dry season were color, 1.00TCU; turbidity, $1.10 \mathrm{NTU}$; temperature, $27.70^{\circ} \mathrm{C} ; \mathrm{pH}$, 5.60; electrical conductivity, $130.00 \mu \mathrm{sm} / \mathrm{cm}$, total dissolved solids, $79.00 \mathrm{mg} / \mathrm{l}$ and total suspended solids, $7.00 \mathrm{mg} / 1$ while the values obtained during the wet season were colour, 1.50 TCU; turbidity, $1.80 \mathrm{NTU}$; temperature, $27.10^{\circ} \mathrm{C}$; electrical conductivity, $136.00 \mu \mathrm{sm} / \mathrm{cm}$, total dissolved solids, $103.00 \mathrm{mg} / \mathrm{l}$ and total suspended solids, $8.00 \mathrm{mg} / \mathrm{l}$. The average values of the physical parameters during the dry and wet seasons were 1.25 TCU, 1.45 NTU, $27.40^{\circ} \mathrm{C}, 5.45,133.00 \mu \mathrm{s} / \mathrm{cm}, 91.00 \mathrm{mg} / \mathrm{l}$ and $7.50 \mathrm{mg} / \mathrm{l}$ for the colour, turbidity, temperature, $\mathrm{pH}$, electrical conductivity, total dissolved solids and total suspended solids respectively.

Table 1. Physical Parameters investigated in the water samples during the dry and wet seasons

\begin{tabular}{|c|c|c|c|c|}
\hline Parameters & $\begin{array}{c}\text { Dry } \\
\text { season }\end{array}$ & $\begin{array}{c}\text { Wet } \\
\text { season }\end{array}$ & $\begin{array}{c}\text { Average } \\
\text { values }\end{array}$ & $\begin{array}{c}\text { WHO } \\
\text { Standard }\end{array}$ \\
\hline Colour (TCU) & 1.00 & 1.50 & 1.25 & 15.00 \\
\hline $\begin{array}{l}\text { Turbidity } \\
\text { (NTU) }\end{array}$ & 1.10 & 1.80 & 1.45 & 5.00 \\
\hline $\begin{array}{l}\text { Temperature } \\
\left({ }^{0} \mathrm{C}\right)\end{array}$ & 27.70 & 27.10 & 27.40 & $25-30$ \\
\hline $\mathrm{pH}$ & 5.60 & 5.30 & 5.45 & $6.5-8.5$ \\
\hline $\begin{array}{c}\text { Electrical } \\
\text { conductivity } \\
(\mu \mathrm{s} / \mathrm{cm})\end{array}$ & 130.00 & 136.00 & 133.00 & 1000 \\
\hline $\begin{array}{l}\text { Total dissolved } \\
\text { solids (mg/l) }\end{array}$ & 79.00 & 103.00 & 91.00 & 500 \\
\hline $\begin{array}{l}\text { Total suspended } \\
\text { solids }(\mathrm{mg} / \mathrm{l})\end{array}$ & 7.00 & 8.00 & 7.50 & 25 \\
\hline
\end{tabular}

The chemical parameters investigated in the water samples during the dry and wet seasons are presented in
Table 2 . The values obtained during the dry season were $0.02 \mathrm{mg} / 1,3.20 \mathrm{mg} / 1,9.10 \mathrm{mg} / 1,60.94 \mathrm{mg} / 1,4.51 \mathrm{mg} / 1,0.11$ $\mathrm{mg} / 1,2.00 \mathrm{mg} / \mathrm{l}$ and $15.60 \mathrm{mg} / \mathrm{l}$ for total acidity, total hardness, total chloride, sulphate, nitrate, nitrite, biological oxygen demand and chemical oxygen demand. However, the values obtained for the total acidity, total hardness, total chloride, sulphate, nitrate, nitrite, biological oxygen demand and chemical oxygen demand during the wet season were $0.21 \mathrm{mg} / 1,2.80 \mathrm{mg} / 1,10.00 \mathrm{mg} / 1,60.90 \mathrm{mg} / \mathrm{l}$, $5.09 \mathrm{mg} / 1,0.18 \mathrm{mg} / 1,2.30 \mathrm{mg} / \mathrm{l}$ and $29.10 \mathrm{mg} / 1$ respectively. The average values of the total acidity, total hardness, total chloride, sulphate, nitrate, nitrite, biological oxygen demand and chemical oxygen demand were $0.12 \mathrm{mg} / 1$, $3.00 \mathrm{mg} / 1, \quad 9.55 \mathrm{mg} / 1, \quad 60.92 \mathrm{mg} / 1, \quad 4.80 \mathrm{mg} / 1, \quad 0.15 \mathrm{mg} / 1$, $2.15 \mathrm{mg} / 1$ and $22.35 \mathrm{mg} / 1$ respectively, during both the dry and wet seasons.

Table 2. Chemical Parameters investigated in the water samples during the dry and wet seasons

\begin{tabular}{ccccc}
\hline Parameters & $\begin{array}{c}\text { Dry } \\
\text { season }\end{array}$ & $\begin{array}{c}\text { Wet } \\
\text { season }\end{array}$ & $\begin{array}{c}\text { Average } \\
\text { values }\end{array}$ & $\begin{array}{c}\text { WHO } \\
\text { Standard }\end{array}$ \\
\hline $\begin{array}{c}\text { Total acidity } \\
(\mathrm{mg} / \mathrm{l})\end{array}$ & 0.02 & 0.21 & 0.12 & $4.5-8.0$ \\
$\begin{array}{c}\text { Total hardness } \\
(\mathrm{mg} / \mathrm{l})\end{array}$ & 3.20 & 2.80 & 3.00 & 200 \\
$\begin{array}{c}\text { Total chloride } \\
(\mathrm{mg} / \mathrm{l})\end{array}$ & 9.10 & 10.00 & 9.55 & 250 \\
$\begin{array}{c}\text { Sulphate (mg/l) } \\
\text { Nitrate (mg/l) }\end{array}$ & 60.94 & 60.90 & 60.92 & 250 \\
$\begin{array}{c}\text { Nitrite (mg/l) } \\
\text { Biological }\end{array}$ & 0.11 & 0.18 & 0.15 & 10 \\
$\begin{array}{c}\text { oxygen demand } \\
(\mathrm{mg} / \mathrm{l})\end{array}$ & 2.00 & 2.30 & 2.15 & $2-6$ \\
$\begin{array}{c}\text { Chemical } \\
\text { oxygen demand } \\
(\mathrm{mg} / \mathrm{l})\end{array}$ & 15.60 & 29.10 & 22.35 & 7.5 \\
\hline
\end{tabular}

The heavy metals parameters investigated in the water samples during the dry and wet seasons are presented in Table 3. The values obtained for iron, lead and aluminum were $0.01 \mathrm{mg} / 1,0.02 \mathrm{mg} / 1$ and $0.14 \mathrm{mg} / 1$ respectively during both seasons. However, the values obtained for zinc and copper during the dry season were $0.91 \mathrm{mg} / \mathrm{l}$ and 0.08 $\mathrm{mg} / \mathrm{l}$ respectively while during the wet season, the values obtained for zinc and copper were $0.89 \mathrm{mg} / \mathrm{l}$ and $0.09 \mathrm{mg} / \mathrm{l}$ respectively. The average values of iron, lead, zinc, copper and aluminum were $0.01 \mathrm{mg} / \mathrm{l}, \quad 0.02 \mathrm{mg} / 1, \quad 0.90 \mathrm{mg} / \mathrm{l}$, $0.09 \mathrm{mg} / 1$ and $0.14 \mathrm{mg} / 1$ respectively for both seasons.

Table 3. Heavy metals parameters investigated in the water samples during the dry and wet seasons

\begin{tabular}{ccccc}
\hline Parameters & $\begin{array}{c}\text { Dry } \\
\text { season }\end{array}$ & $\begin{array}{c}\text { Wet } \\
\text { season }\end{array}$ & $\begin{array}{c}\text { Average } \\
\text { values }\end{array}$ & $\begin{array}{c}\text { WHO } \\
\text { Standard }\end{array}$ \\
\hline Iron (mg/l) & 0.01 & 0.01 & 0.01 & 0.30 \\
Lead (mg/1) & 0.02 & 0.02 & 0.02 & 0.01 \\
Zinc (mg/l) & 0.91 & 0.89 & 0.90 & 3.00 \\
$\begin{array}{c}\text { Copper (mg/l) } \\
\text { Aluminum } \\
(\mathrm{mg} / \mathrm{l})\end{array}$ & 0.08 & 0.09 & 0.09 & 2.0 \\
\hline
\end{tabular}




\section{Discussion}

Colour in drinking water is usually due to the presence of organic matter (primarily humic and fulvic acids) associated with the humus fraction of soil or the presence of iron and other metals, either as natural impurities or as corrosion products [9]. Pure water has a slight blue color that becomes a deeper blue as the thickness of the observed sample increases, though relatively small quantities of water appear to be colorless. The blue colour of water is an intrinsic property and is caused by selective absorption and scattering of white light. Impurities dissolved or suspended in water may give water different colored appearances. The colour of the stream studied during both seasons (Table 1) did not exceed the limit prescribed by WHO [10] and there was no significant seasonal variation in colour. This result with the report of Krishna et al. [11] on Kaveri river, India.

Turbidity relatively measures the cloudiness of a water source and is an indicator of water pollution. It is caused by materials suspended in water [12]. The values were within the WHO recommended limit during both seasons (Table 1). The result of the study agreed with the report of Udousoro and Umoren [13] on the assessment of surface and ground water quality. Increase in turbidity of water results in interference of the penetration of light [14]. Temperature plays a critical role in the metabolic activities of organisms and also affects the solubility of oxygen in water $[15,16]$. The temperature values during both seasons were within the WHO limit of $30^{\circ} \mathrm{C}$ (Table 1). The result agreed with the results of Akubuenyi et al. [17] on some of the sources of water studied in Calabar, Nigeria and Jaji et al. [18] on water quality assessment of Ogun River, Nigeria.

$\mathrm{pH}$ is used to express the intensity of the acid or alkaline condition of a solution [19]. The $\mathrm{pH}$ was slightly different in values during the dry and wet seasons (Table 1) and was not within the WHO (6.5-8.5) limit, which indicated that the water was slightly acidic. This result agreed with the report of Ukpong and Peter [20] on the physiochemical parameters in drinking water in Ibeno Local Government Area of Akwa Ibom State. The acidic nature of the water source can be attributed to a number of factors such as the presence of organic acids from decaying vegetation [21, 22], dissolved carbon dioxide and the dissolution of sulphide minerals. Water in a pure state is neither acidic nor basic.

Electrical conductivity is a measure of the capacity of a water sample to conduct electric current as well as the relative level of total dissolved salts in the water $[15,19]$. The electrical conductivity of the stream during both seasons were within the WHO recommended limit (Table 1). Similar results were obtained by Udousoro and Umoren [13] in their assessment of surface and ground water quality. Higher values of electrical conductivity may be attributed to concentrated dissolved salts as a result of human activities [23].
Total Dissolved Solids (TDS) is a measure of both anions and cations in a water body. Total dissolved solids in ground and surface water could come from natural and or anthropogenic sources such as industrial waste water, sewage, urban runoff and the chemicals used in the treatment of water $[15,24]$. The TDS during both seasons were within the WHO acceptable limit (Table 1). The result also agreed with the report of Udousoro and Umoren [13] on surface and ground water quality.

Total Suspended Solids (TSS) in water affect the aesthetic appeal of bathing water. Water that is high in TSS is more of an aesthetic than a health hazard [8]. TSS is a precursor to turbidity due to silt and organic matter $[25,26]$. The values obtained in both seasons were within the WHO limit (Table 1) and agreed with the results of Edet et al. [27] on the bacteriological and physicochemical quality of stream water in Nduetong Oku, Community, Uyo, Akwa Ibom State, Nigeria.

There was no significant seasonal variation in the total acidity obtained during both seasons. This result agreed with Krishna et al. [11] who observed no significant seasonal variation in the physicochemical parameters investigated in Kaveri river, India. The water $\mathrm{pH}$ could be lower during the dry season if the free $\mathrm{CO}_{2}$ released during respiration of aquatic organisms reacts with water, producing carbonic acid. The values during both seasons were within the WHO range for potable water (Table 2). The acidity of water is its quantitative capacity to react with strong base. Strong mineral acids and weak acids such as carbonic and acetic as well as hydrolysing salts such as aluminum or iron sulphates may contribute to measured acidity [8].

Hardness of the water is the property that decreases the lather formation of soap and increases scale formation in hot - water heaters and low - pressure boiler at high levels. Total hardness is mainly due to calcium and magnesium salts $[15,19]$ and is derived from limestone or industrial effluents. The value for total hardness in this study did not exceed the WHO limit (Table 2). The values of total hardness obtained in the present study were similar to those reported by Essumang et al. [28] for ground water. The water from the stream during both seasons should be described as soft water based on WHO [7] classification.

The total chloride values obtained during both seasons were within the WHO standard (Table2). The chloride content agreed with the report of Udousoro and Umoren [13] who obtained values that were within the WHO limit. Chloride in water may be as a result of anthropogenic source of pollution such as sewage, septic system, landfill, industrial effluents and fertilizer [28, 29]. Higher chloride concentration in water can give rise to detectable taste in water.

Sulfate can be naturally-occurring or may result from municipal or industrial discharges. When naturally occurring, they are often the result of the breakdown of leaves that fall into a stream passing through rock or soil 
containing gypsum and other common minerals or of atmospheric deposition. Point sources include sewage treatment plants and industrial discharges such as tanneries, pulp mills and textile mills. Runoff from fertilized agricultural lands also contributes sulphates to water bodies. At high levels, sulphate can give water a bitter or astringent taste and can have laxative effects. The results obtained for sulphates in this study during both seasons were within the WHO limit (Table 2) and agreed with those of Solomon and Kehinde [30] on the physicochemical properties of a flowing stream in Jabi, Abuja, Nigeria.

The values for nitrate and nitrite were within the WHO limit for drinking water (Table 2). The result agreed with Ukpong and Peter [20] who reported values that were within the WHO limit and observed seasonal variations in physicochemical parameters of the water samples they studied. Nitrate is most highly oxidized form of nitrogen compounds and is commonly present in surface and ground water. Unpolluted water contains minute amount of nitrate $[18,31]$. Nitrates are the final products of the biochemical oxidation of ammonia [25]. High nitrate concentration in drinking water has been reported to have detrimental effects on pregnant women and babies less than six months old [32] and could be a source of eutrophication in the receiving water. Nitrite occurs as an intermediate product in the nitrification process of ammonia [33]. It is harmful and can oxidize haemoglobin to methemoglobin in the body and hinder the transportation of oxygen around the body.

Biochemical oxygen demand indicates the amount of organic waste present in water. $\mathrm{BOD}_{5}$ values during both seasons were within the WHO acceptable limit (Table2). $\mathrm{BOD}_{5}$ value of $3 \mathrm{mg} / \mathrm{l}$ in surface water has been reported to show sewage contamination through runoff. The BOD result did not agree with the report of Nidhi et al. [34] who observed high BOD $(48.5-51.35 \mathrm{mg} / \mathrm{l})$ above the WHO limit in the samples from the river that they studied.

There was a slight variation in the chemical oxygen demand during both seasons and the values obtained were higher than the WHO limits (Table2). The higher COD level indicated high organic pollution as well as interference from inorganic ions [35]. Chemical oxygen demand is a measure of the capacity of water to consume oxygen during the decomposition of organic matter and the oxidation of inorganic chemicals such as ammonia and nitrite. The COD results agreed with the report of Nidhi et al. [34] who observed high COD (211-215.3mg/l) above the WHO limit in the samples from the river that they assessed.

The values obtained for the heavy metals during both seasons were within the WHO limits (Table3) except the lead level. Heavy metals are needed at low levels as catalyst for enzyme activities. The results obtained for the zinc and copper agreed with the report of Ukpong and Peter [20] who observed slight seasonal variations in heavy metals parameters in drinking water in Ibeno Local
Government Area of Akwa Ibom State. Iron is essential in the metabolism of plants and animals. If present in excessive amounts however, it forms oxyhydrate precipitates that stain laundry and porcelain. High levels of these essential metals may be hazardous to human health [17]. Its contact with water sources could be through weathering of rocks and leaching.

\section{Conclusions}

The quality of the stream water studied was acceptable in terms of the majority of the physicochemical parameters studied during both seasons. However, the samples did not comply with WHO standard in terms of $\mathrm{pH}$, chemical oxygen demand and lead level. In addition, there was no significant variation in the physicochemical parameters of the stream during the dry and wet seasons. The water from the stream must therefore be subjected to adequate treatment before drinking and other domestic uses.

\section{Recommendations}

Government should organize a program to educate the populace on the proper disposal of refuse and treatment of sewage before discharge into the environment including Iyifeyi stream. In addition, Government and non-governmental organizations should also render assistance by providing potable water supply to the Ugwobi Abbi Community. Treatment of the stream water before drinking is imperative to avert a public health problem.

\section{REFERENCES}

[1] Ajewole, I.A. (2005). Water: An Overview. Food Forum. 4(1): 15-16.

[2] Shittu, O.B., Olaitan, J.O. and Amusa, T.S. (2008). Physicochemical and bacteriological analyses of water used for drinking and swimming purposes. African Journal of Biomedical Research. 11:285-286.

[3] Ajayi, A.O. and Akonai, K. A. (2005). Distribution pattern of enteric organisms in the Lagos. African Journal of Biomedical Research. 8(3): 163-168.

[4] Mason, R. P., Lawson, N. M. and Sheu, G. R. (2001). Mercury in the Atlantic Ocean: Factors controlling air-sea exchange of mercury and its distribution in the upper waters. Deep Sea Research, Part II. (48): 2829-2853.

[5] Hazelnot, D.G. (2000). The development of effective community water supply system using deep and shallow well handpumps. WRC Report No: TT 132/00. South Africa. Pp 12-20.

[6] World Health Organization (2003). Guidelines for drinking water quality. 4th ed. WHO Press, Geneva, Switzerland. Pp 
8-17.

[7] World Health Organization (2004). Guideline for drinking water quality recommendation. WHO.1:130

[8] American Public Health Association. (2005). Standard methods for the examination of water and wastewater ( $21^{\text {st }}$ ed.). Washington D.C. Pp 80-82.

[9] Bernard, E. and Ayeni, N. (2012). Physicochemical analysis of ground water samples of Bichi Local Government Area of Kano of Nigeria. World Environment. 2(6): 116 - 119.

[10] World Health Organization (2006). Guidelines for drinking water quality. 6th ed. WHO Press, Geneva, Switzerland. Pp $12-13$.

[11] Krishna, P., Jayashnakar, M. and Shankar, H. (2011). Physicochemical and bacteriological parameters of Kaveri river. National Monthly Refereed Journal of Research in Science \& Technology. 1(6): 12-13.

[12] Chandra, S; Singh, P.K; Tomar and Kumar, A. (2011). Evaluation of physicochemical characteristics of various River Water of India. E-Journal of Chemistry. 8(4): 1546 1555.

[13] Udousoro, I. and Umoren, I. (2014). Assessment of surface and groundwater quality. Journal of Natural Sciences Research. 4(6): 11-16.

[14] Gupta, N; Pandey, P. and Hussain, J. (2017). Effect of physicochemical and biological parameters on the quality of River Water of Narmada Madhya Pradesh India. Water Science. 31: 11-23.

[15] Gopalkrushna, M.H. (2011). Assessment of physicochemical status of ground water samples in Akot city. Research Journal of Chemical Sciences. 1(4): 117-124.

[16] Kataria, H. C., Gupta, M; Kumar, M; Kushwaha, S; Kashyap, S; Trivedi S; Bhadoriya, R. and Bandewar, N. K. (2011). Study of physicochemical parameters of drinking water of Bhopal City with reference to Health Impacts. Current World. 6(1): 95-99.

[17] Akubuenyi, F.C., Enyi-Ido and Utta, E.C. (2013). Microbiological and physicochemical assessment of major sources of water for domestic uses in Calabar metropolis. Transnational Journal of Science and Technology. 3(2): 31-36.

[18] Jaji, M. O., Bangbose, O; Odukoya, O. O. and Arowlo, T. A. (2007). Water quality assessment of Ogun River, South West Nigeria. Environmental Monitoring and Assessment. 133 (1-3): 447 - 482.

[19] Chadne, S. J. (2014). Physicochemical parameters of the drinking water of some villages of Yavatural district, Maharashtra (India). Journal of Science Research and Studies. 1-4.

[20] Ukpong, E.C. and Peter, B.U. (2012). Physicochemical and bacteriological analyses of drinking water. Nigeria Journal of Technology. 31(2): 116-117.

[21] Paschke, S.S., Harrison, W.J. and Walton-Day, K. (2001). Effects of acid research on groundwater at the St. Kelvin Gulch site, leadville, Colorado. Geochemistry: Exploration, Environment and Analysis. 1(1): 3 - 14.
[22] Verplanck, P.I, Nordstrom, D.K., Plumlee, G. S., Wanty, R. B., Bove, D.J. and Caine, J. S. (2006). Hydrogeochemical controls on surface and groundwater chemistry in natural acidic porphyry-related mineralised areas, Southern Rocky Mountains. Chinese Journal of Geochemistry. 25: 231- 241.

[23] Chindo, I. Y; Karu, E; Ziyok, I. and Amanki, E.D. (2013). Physicochemical analysis of groundwater of selected areas of Dass and Ganjuwa Local Government Area, Bauchi State, Nigeria. World Journal of Analytical Chemistry. 1(4): 73 79.

[24] Saana, S.B.B.M; Fosu, S. A., Sebiawu, G.E; Jackson, N. and Karikan, T. (2016). Assessment of the quality of groundwater for drinking purposes in the Upper West and Northern regions of Ghana. Springerplus. 5: 2001.

[25] Mahananda, M., Mohanty, B. and Bhera, N. (2010). Physicochemical analysis of surface and ground water of Bargarh District, Orissa, India. International Journal of Research and Reviews in Applied Sciences. 2(3): 284-295.

[26] Magadum A; Patel, P. and Gavali, D. (2017). Assessment of physicochemical parameters and water quality index of Vishwamitri River, Gujarat, India. International Journal of Environment, Agriculture and Biotechnology. 2(4): 1505 1510.

[27] Edet, E. J., Etim, E.E. and Titus, O. M. (2012). Bacteriological and physicochemical analysis of streams water in Nduetong Oku community, Uyo. International Journal of Modern Chemistry. 3(1):65-67.

[28] Essumang, D. K., Senu, J., Fianko, J., Nyarko, B., Adokoh, C. and Boamponsem, L. (2011). Groundwater quality assessment: Physicochemical properties of drinking water in rural setting of developing countries. Canadian Journal on Scientific and Industrial Research. 2(3): 102-126.

[29] Hamaidi, M. S. and Chergui, F. H. (2014). Physicochemical quality of boreholes used as a source of public supply in Arib (Ani-Defla, Algeria). European Academic Research. 1 (12): $5379-5392$.

[30] Solomon, R. J. and Kehinde, O. A. (2017). Physicochemical properties of a flowing Stream in Jabi, Abuja, Nigeria. Direct Research Journal of Biology and Biotechnology. 3(1): $24-29$.

[31] Shawai, S. A. A; Kutama, R. M; Abubakar, B. B. and Muazu, J. (2018). Evaluation of physicochemical characteristics of groundwater from selected areas of Unguwa Uku, Kano Metropolitan, North Western Nigeria. International Journal of Biomedical Materials Research. 6(1): 8 -12.

[32] Longe, E. and Balogun, M. (2010). Groundwater quality assessment near a municipal landfill, Lagos, Nigeria. Research Journal of Applied Sciences, Engineering and Technology. 2(1): 39-44.

[33] Elleta, O., Adeniyi, A. and Dolapo, A. (2010). Physicochemical characterisation of some ground water supply in a school environment in Ilorin, Nigeria. African Journal of Biotechnology. 9(22): 3293-3297.

[34] Nidhi, S., Misra, S. N. and Shukla, R. N. (2011). Physicochemical and bacteriological analysis of water quality under different environmental condition. Journal of Chemical and pharmaceutical Research. 3(2):162-167. 
[35] Omonona, A. O; Adetuga, A. T. and Nnamuka, S. S. (2019). Physicochemical and microbiological characteristics of water samples from the Borgu sector of Kainji Lake National
Park, Nigeria. International Journal of Environment and Pollution Research. 7(2): $1-5$. 